\title{
Systematic Literature Review pada Analisis Prediktif dengan IoT: Tren Riset, Metode, dan Arsitektur
}

\author{
Fahrur Rozi \\ Sekolah Teknik Elektro dan Informatika \\ Institut Teknologi Bandung \\ Bandung, Indonesia \\ fahrurrozi@s.itb.ac.id
}

\begin{abstract}
Nowadays IoT researches on intelligent service systems is becoming a trend. IoT produces a variety of data from sensors or smart phones. Data generated from IoT can be more useful and can be followed up if data analysis is carried out. Predictive analytic with IoT is part of data analysis that aims to predict something solution. This analysis utilization produces innovative applications in various fields with diverse predictive analytic methods or techniques. This study uses Systematic Literature Review (SLR) to understand about research trends, methods and architecture used in predictive analytic with IoT. So the first step is to determine the research question (RQ) and then search is carried out on several literature published in popular journal databases namely IEEE Xplore, Scopus and ACM from 2015 - 2019. As a result of a review of thirty (30) selected articles, there are several research fields which are trends, namely Transportation, Agriculture, Health, Industry, Smart Home, and Environment. The most studied fields are agriculture. Predictive analytic with IoT use varied method according to the conditions of data used. There are five most widely used methods, namely Bayesian Network (BN), Artificial Neural Network (ANN), Recurrent Neural Networks (RNN), Neural Network (NN), and Support Vector Machines (SVM). Some studies also propose architectures that use predictive analytic with IoT.
\end{abstract}

Keywords-Predictive Analytic, IoT, Systematic Literature Review, SLR

\section{PENDAHULUAN}

Perkembangan teknologi dan informasi membawa perubahan besar di segala bidang khususnya Internet of Things (IoT). Dengan adanya IoT, sejumlah perangkat yang terhubung ke internet mulai dari sensor dan ponsel pintar meningkat secara signifikan. Pada tahun 2020, jumlah perangkat ini diperkirakan akan meningkat menjadi sekitar 50 milyar [1]. Meningkatnya jumlah perangkat ini menghasilkan jumlah data yang beragam pula. Tersedianya data yang dihasilkan oleh perangkat yang beragam ini telah membuka peluang baru munculnya aplikasi inovatif di berbagai bidang, misalnya sistem transportasi cerdas [2], layanan kesehatan cerdas [3], sistem pertanian cerdas [4] dan lain sebagainya.

Seperti diketahui, IoT mengumpulkan beragam data yang berasal dari sensor, ponsel pintar atau perangkat yang terhubung dengan internet lainnya kemudian menyimpannya di server atau cloud. Data tersebut dapat berupa angka kontinu dari sensor suhu atau gambar/video dari kamera. Untuk mengubah data menjadi informasi atau pengetahuan yang lebih berguna dan dapat ditindaklanjuti, data tersebut harus dilakukan analisis menggunakan metode atau teknik-teknik tertentu. Analisis data ini membutuhkan penggunaan artificial intelligence (AI), machine learning (ML), dan teknik analisis prediktif dengan tujuan untuk menyaring data, mengidentifikasi tren dan memprediksi solusi yang tepat.

Analisis prediktif dengan IoT merupakan bagian dari analisis data yang bertujuan memprediksi data berdasarkan pola yang diekstrak dari data-data historis yang berasal dari data IoT. Analisis prediktif inilah yang membuat sistem terlihat menjadi lebih cerdas. Analisis prediktif dengan IoT sudah banyak diterapkan di berbagai bidang sebagai bagian dari sistem layanan cerdas, misalnya prediksi kemacetan lalu lintas dari data lalu lintas, cuaca dan media sosial pada sistem transportasi cerdas [2], prediksi serangan jantung dari data temperatur dan detak jantung seseorang pada sistem kesehatan cerdas [5], prediksi penyakit tanaman dari data temperatur, kelembaban dan kandungan udara pada sistem pertanian cerdas [4] dan lain-lain.

Data IoT biasanya bersifat heterogen, pertumbuhan datanya cepat, bervolume besar, dan dibutuhkan analisis secara real-time. Teknik analisis prediktif secara tradisional saja tidak cukup untuk menganalisis data kompleks yang dihasilkan oleh IoT [6]. Ada berbagai macam metode atau teknik yang dapat digunakan untuk menganalisis data ini misalnya Artificial Neural Networks (ANN) [7], Bayesian Network (BN) [2], Support Vector Machines (SVM) [8] dan metode lainnya. 
Untuk lebih memahami analisis prediktif dengan IoT, penelitian ini melakukan tinjauan literatur dengan menggunakan Systematic Literature Review (SLR). SLR dapat membantu menemukan solusi dengan melakukan review pada penelitian yang relevan sebelumnya. Tujuan dari penelitian ini adalah memahami tren riset, metode, dan arsitektur yang digunakan pada analisis prediktif dengan IoT. Untuk mendapatkan hasil yang komprehensif, penelitian dilakukan pada beberapa literatur yang diterbitkan pada database jurnal populer misalnya IEEE Xplore, Scopus dan ACM dari tahun 2015 - 2019.

Makalah ini terdiri dari empat bagian. Bagian 2 memberikan penjelasan tinjauan literatur sistematis sebagai metodologi penelitian ini. Bagian 3 menjelaskan hasil tinjauan dan jawaban untuk pertanyaan penelitian. Bagian 4 menyajikan kesimpulan penelitian dan saran untuk pekerjaan di masa depan.

\section{METODOLOGI}

\subsection{Systematic Literature Review}

Systematic Literature Review (SLR) adalah studi sekunder untuk memetakan, mengidentifikasi, mengevaluasi secara kritis, mengkonsolidasikan, dan mengumpulkan hasil studi utama pada topik penelitian tertentu [9]. SLR menjadi metode standar untuk mendapatkan jawaban dengan melakukan tinjauan pustaka berdasarkan studi terkait sebelumnya. Tujuan melakukan SLR adalah untuk merangkum penelitian sebelumnya, untuk mengidentifikasi kesenjangan yang perlu dipenuhi antara penelitian sebelumnya dan saat ini, untuk menghasilkan laporan/sintesis yang koheren, dan untuk membuat kerangka kerja penelitian.

Tujuan studi literatur pada penelitian ini untuk memahami topik riset yang tren, metode, dan arsitektur pada analisis prediktif dengan IoT. Untuk mendapatkan hasil yang komprehensif, penelitian mengambil beberapa literatur yang diterbitkan dari jurnal basis data populer yaitu IEEE Xplore, Scopus, dan ACM dari 2015 hingga 2019.

\subsection{Research Question}

Tujuan dari Research Question (pertanyaan penelitian) adalah untuk mempertahankan fokus tinjauan literatur. Kondisi ini memudahkan proses pencarian data yang diperlukan. Tabel 1 menunjukkan pertanyaan penelitian untuk penelitian ini.

Tabel 1 Research Question

\begin{tabular}{|c|l|l|}
\hline ID & \multicolumn{1}{|c|}{ Research Question } & \multicolumn{1}{|c|}{ Motivasi } \\
\hline RQ1 & $\begin{array}{l}\text { Apa saja topik riset yang tren pada bidang } \\
\text { Analisis Prediktif dengan IoT? }\end{array}$ & $\begin{array}{l}\text { Identifikasi topik riset yang tren pada bidang Analisis } \\
\text { Prediktif dengan IoT }\end{array}$ \\
\hline RQ2 & $\begin{array}{l}\text { Apa saja metode yang digunakan pada Analisis } \\
\text { Prediktif dengan IoT? }\end{array}$ & $\begin{array}{l}\text { Identifikasi metode yang digunakan pada Analisis } \\
\text { Prediktif dengan IoT }\end{array}$ \\
\hline RQ3 & $\begin{array}{l}\text { Apa saja arsitektur pada Analisis Prediktif } \\
\text { dengan IoT? }\end{array}$ & $\begin{array}{l}\text { Identifikasi arsitektur pada Analisis Prediktif dengan } \\
\text { IoT }\end{array}$ \\
\hline
\end{tabular}

\subsection{Hasil Pencarian}

Untuk menjawab Research Question yang sudah dijelaskan di atas, penelitian melakukan pencarian pada database jurnal populer dengan kata kunci spesifik untuk pencarian. Kata kunci yang digunakan yaitu : predict* AND IoT AND (analy* OR method OR technique OR architecture). Pencarian dengan kata kunci tersebut dilakukan pada bagian abstrak saja. Hasil pencarian ditemukan sebanyak 674 artikel. Tabel 2 menunjukkan hasil dari proses pencarian menggunakan kata kunci tersebut.

Tabel 2 Hasil Pencarian Penelitian Terkait

\begin{tabular}{|l|l|c|}
\hline No & \multicolumn{1}{|c|}{ Jurnal Database } & Jumlah Artikel \\
\hline 1 & IEEE Xplore & 475 \\
\hline 2 & Scopus & 125 \\
\hline 3 & ACM $\quad 74$ \\
\hline \multicolumn{2}{|c|}{ Total } & 674 \\
\hline
\end{tabular}

(C)Asosiasi Prakarsa Indonesia Cerdas (APIC) - 2020 
Kriteria inclusion dan exclusion digunakan untuk memilih penelitian utama. Hasil artikel dari kriteria inilah yang nantinya akan di-review oleh peneliti. Adapun kriteria inclusion dan exclusion dapat dilihat pada tabel 3.

Tabel 3 Kriteria Inclusion dan Exclusion

\begin{tabular}{|l|l|l|}
\hline $\begin{array}{l}\text { Kriteria } \\
\text { Inclusion }\end{array}$ & I1 & $\begin{array}{l}\text { Artikel yang berhubungan dengan tren, metode/teknik dan arsitektur pada analisis prediktif } \\
\text { dengan IoT } \\
\text { Artikel ditulis dengan Bahasa Inggris } \\
\text { I2 }\end{array}$ \\
\hline $\begin{array}{l}\text { I3 } \\
\text { Exiteria } \\
\text { Exclusion }\end{array}$ & E1 & $\begin{array}{l}\text { Artikel dapat diakses secara penuh } \\
\text { Artikel jurnal yang tidak terindeks Q1, Q2 dan Q3 } \\
\text { Artikel conference yang tidak berperingkat }\end{array}$ \\
\hline
\end{tabular}

Setelah melakukan filtering dengan kriteria inclusion dan exclusion pada artikel hasil pencarian menggunakan kata kunci maka diperoleh beberapa artikel jurnal dan konferensi yang ditunjukkan pada tabel 4 . Jumlah artikel yang diperoleh sebanyak 30 artikel baik jurnal maupun konferensi. Artikel inilah yang akan direview pada penelitian ini.

Tabel 4 Hasil Proses Filtering

\begin{tabular}{|l|l|c|}
\hline No & \multicolumn{1}{|c|}{ Publikasi } & Jumlah Artikel \\
\hline 1 & Jurnal Q1 & 11 \\
\hline 2 & Jurnal Q2 & 8 \\
\hline 3 & Jurnal Q3 & 1 \\
\hline 4 & Conference & 10 \\
\hline \multicolumn{2}{|c|}{ Total } & 30 \\
\hline
\end{tabular}

\section{HASIL PENELITIAN}

\subsection{Tren Penelitian di Analisis Prediktif dengan IoT}

Berdasarkan hasil tinjauan pustaka, terdapat enam bidang penelitian yang tren pada analisis prediktif dengan IoT yaitu Transportasi, Pertanian, Kesehatan, Industri, Smart Home, dan Lingkungan. Saat ini, bidang yang paling banyak diteliti adalah bidang pertanian. Tabel 5 menunjukkan tren bidang penelitian analisis prediktif dengan IoT dan referensinya.

Tabel 5 Bidang Penelitian Analisis Prediktif dengan IoT

\begin{tabular}{|l|l|l|}
\hline No & \multicolumn{1}{|c|}{ Bidang } & \multicolumn{1}{c|}{ Referensi } \\
\hline 1. & Pertanian & {$[4][7][14][15][16][17][18]$} \\
\hline 2. & Transportasi & {$[2][6][10][11][12][13]$} \\
\hline 3. & Kesehatan & {$[3][5][19][20][21][22]$} \\
\hline 4. & Lingkungan & {$[28][29][30][31]$} \\
\hline 5. & Smart Home & {$[1][25][26][27]$} \\
\hline 6. & Industri & {$[8][23][24]$} \\
\hline
\end{tabular}


Saat ini. bidang pertanian merupakan topik analisis prediktif dengan IoT yang paling banyak diteliti. Penerapan analisis prediktif pada bidang ini antara lain prediksi cuaca ekstrim yang akan mempengaruhi tanaman [14][16], prediksi pertumbuhan ikan dan tanaman [15], prediksi penyakit tanaman [4][18], pemantauan pertumbuhan tanaman [17], dan prediksi stres pada sapi perah [7]. Penerapan analisis prediktif dengan IoT memiliki potensi yang besar pada sektor pertanian. Hal ini sangat membantu petani untuk meningkatkan produktivitas hasil pertanian.

Pada bidang transportasi, topik yang diteliti antara lain prediksi kemacetan lalu lintas [2][6][10][11][12] dan prediksi ketersedian parkir [13]. Seperti diketahui, kota-kota besar di dunia memiliki permasalahan utama yakni kemacetan lalu lintas. Dengan pengembangan Sistem Transportasi Cerdas dan IoT, yang didalamnya terdapat prediksi kemacetan lalu lintas secara real time, hal ini dapat menjadi solusi untuk menanggulangi permasalahan kemacetan. Salah satu manfaatnya adalah para pengguna transportasi dapat menghindari jalan-jalan yang macet agar tidak bertambah parah.

Pada bidang kesehatan, topik yang diteliti antara lain smart log pemantauan nutrisi makanan anak [19], deteksi dini penyakit [3][20][21] dan prediksi penurunan tekanan darah [22]. Salah satu manfaat analisis prediktif dengan IoT pada bidang ini yaitu monitoring kesehatan secara real-time untuk deteksi dini penyakit yang mengancam jiwa melalui teknologi penginderaan dan komunikasi canggih sehingga dapat memberikan pengobatan yang lebih baik, mengurangi biaya medis dan menyelamatkan nyawa manusia.

Penerapan di bidang lingkungan sangat membantu terwujudnya perlindungan lingkungan, misalnya prediksi kualitas udara atau air [29], atau kondisi atmosfer atau tanah [30]. Tidak hanya itu saja, analisis prediktif dengan IoT dapat dimanfaatkan dalam penanggulangan bencana semacam sistem peringatan dini [28]. Hal ini tentunya sangat membantu keselamatan kehidupan manusia pada daerah-daerah rawan bencana.

Smart home yang bertujuan untuk meningkatkan kenyamanan penghuninya tentu menjadi topik penelitian yang tren. Aplikasi analisis prediktif pada bidang ini antara lain pemanfaatan energi secara optimal dengan mengoperasikan peralatan hanya saat dibutuhkan [25][26][27] dan prediksi penggunaan air [27]. Salah satu manfaat yang diperoleh adalah pengurangan konsumsi energi listrik sebanyak mungkin.

Pada bidang industri, analisis prediktif dengan IoT sangat dibutuhkan. Topik yang diteliti antara lain manajemen aset untuk prediksi pemeliharaan aset [8], pencegahan kecelakaan keselamatan pekerja dan memprediksi siklus penggantian untuk manajemen motor di bidang robot industri [23]. Penggunaan IoT dalam memprediksi pemeliharaan aset sangat bermanfaat untuk mengidentifikasi potensi masalah sebelum terjadinya kerusakan pada mesin.

\subsection{Metode yang digunakan di Analisis Prediktif dengan IoT}

Hasil review ditemukan bahwa terdapat dua puluh tiga jenis metode yang digunakan pada analisis prediktif dengan IoT. Metode yang digunakan berupa algoritma atau model. Perbedaan metode dipengaruhi oleh kondisi data yang digunakan baik data prediktor maupun data prediksi. Tabel 6 menunjukkan daftar metode yang digunakan dalam analisis prediktif dengan IoT.

Berdasarkan dua puluh tiga jenis metode yang ditunjukkan pada tabel 6, ada terdapat lima metode yang paling banyak digunakan yaitu Bayesian Network (BN), Artificial Neural Network (ANN), Recurrent Neural Networks (RNN), Neural Network (NN), dan Support Vector Machines (SVM). 


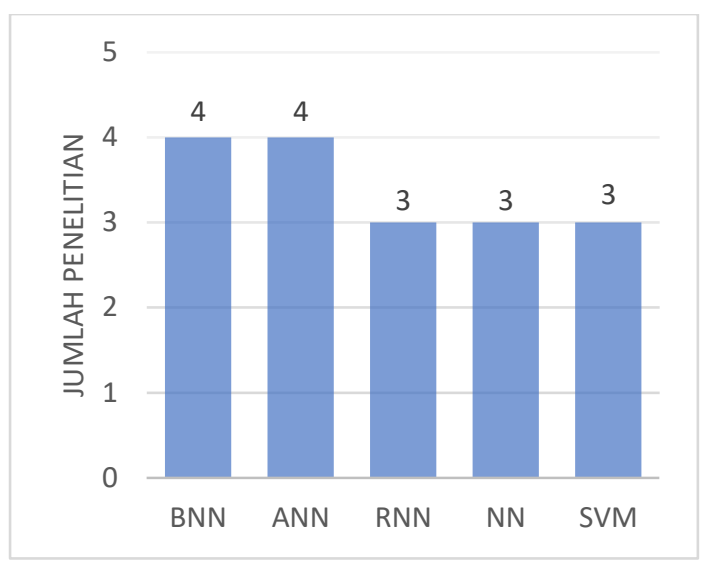

Gambar 1 Metode yang paling banyak digunakan

Beberapa penelitian pada analisis prediktif dengan IoT melaporkan perbandingan performa metode yang digunakan. Penelitian prediksi kemacetan pada jaringan transportasi berskala besar membandingkan empat metode prediktif yaitu RNN-RBM, BPNN, dan SVM [10]. Hasilnya menunjukkan metode yang menggunakan RNN-RBM memiliki tingkat akurasi paling baik dibandingkan metode lainnya. Penelitian prediksi ketersediaan parkir membandingkan tiga metode algoritma yaitu RT, NN dan SVR [13]. Evaluasi menunjukkan bahwa RT merupakan algoritma intensif komputasi paling sedikit dan performa prediksinya paling baik dibandingkan kedua metode lainnya yaitu NN dan SVR. K-NN, Naïve Bayes, SVM dan ANN digunakan untuk memprediksi perangkat pada smart home yang dapat dimatikan [1]. Evaluasi menunjukkan algoritma K-NN memiliki performa prediksi yang paling baik dibandingkan ketiga metode lainnya.

Tabel 6 Metode Analisis Prediktif dengan IoT

\begin{tabular}{|l|l|l|}
\hline No & \multicolumn{1}{|c|}{ Metode } & \multicolumn{1}{|c|}{ Referensi } \\
\hline 1. & Adaptive Moving Window Regression (AMWR) & {$[6]$} \\
\hline 2. & Bayesian Network (BN) & {$[2][14][23][19]$} \\
\hline 3. & Random Forest (RF) & {$[14]$} \\
\hline 4. & Recurrent Activity Predictor (RAP) & {$[25]$} \\
\hline 5. & Holt's Linear Trend Method & {$[3]$} \\
\hline 6. & Hidden Markov Model & {$[26]$} \\
\hline 7. & Restricted Boltzmann Machine (RBM) & {$[10][8]$} \\
\hline 8. & Artificial Neural Network (ANN) & {$[31][29][1][7]$} \\
\hline 9 & Robustness Analysis & {$[15]$} \\
\hline 10 & General Infection Model & {$[4]$} \\
\hline 11 & Recurrent Neural Networks (RNN) & {$[10][20][27]$} \\
\hline 12 & Back Propagation Neural Network (BPNN) & {$[10]$} \\
\hline 13 & Hybrid Prediction Model (HPM) & {$[21]$} \\
\hline 14 & ARIMA & {$[16]$} \\
\hline 15 & Neural Network (NN) & {$[16][13][8]$} \\
\hline 16 & Decision Tree & {$[17][30]$} \\
\hline 17 & Dynamic Bayesian Networks (DBN) & {$[11][12]$} \\
\hline 18 & Multiple Regression & {$[22][8]$} \\
\hline 19 & Regression Tree (RT) & {$[13]$} \\
\hline
\end{tabular}




\begin{tabular}{|l|l|l|}
\hline No & \multicolumn{1}{|c|}{ Metode } & \multicolumn{1}{|c|}{ Referensi } \\
\hline 20 & Support Vector Regression (SVR) & {$[13]$} \\
\hline 21 & K-Nearest Neighbor (KNN) & {$[1][24]$} \\
\hline 22 & Naive Bayes & {$[1]$} \\
\hline 23 & Support Vector Machines (SVM) & {$[10][1][18][8]$} \\
\hline
\end{tabular}

Beberapa peneliti mengusulkan metode perbaikan dari beberapa metode yang biasanya digunakan. Pada prediksi kemacetan lalu lintas menggunakan metode prediksi adaptif yang dinamakan AMWR[6]. Metode AMWR digunakan untuk data IoT yang dinamis. Metode ini terdiri dari tiga langkah utama yaitu pemilihan algoritma regresi, menemukan optimum training window size, dan ukuran horizon prediksi. Tingkat akurasi prediksi yang dihasilkan dengan metode AMWR menunjukkan angka yang lebih baik.

\subsection{Arsitektur pada Analisis Prediktif dengan IoT}

Berdasarkan tinjauan pustaka, terdapat empat arsitektur diusulkan yang menggunakan analisis prediktif dengan IoT yaitu Arsitektur Akbar dkk [6], Arsitektur Abdulatif dkk [3], Arsitektur Jo dkk [29], dan Arsitektur Patil dkk [17].

\subsubsection{Arsitektur Akbar dkk}

Akbar dkk mengusulkan dan mengimplementasikan arsitektur generik berdasarkan komponen open source untuk menggabungkan machine learning (ML) dengan pemrosesan kejadian kompleks atau complex event processing (CEP). Adapun tujuannya adalah memprediksi peristiwa kompleks pada aplikasi IoT proaktif. Arsitektur ini menggunakan data historis dan data real time. Gambar 2 menunjukkan arsitektur yang diusulkan Akbar dkk pada sistem transportasi cerdas.

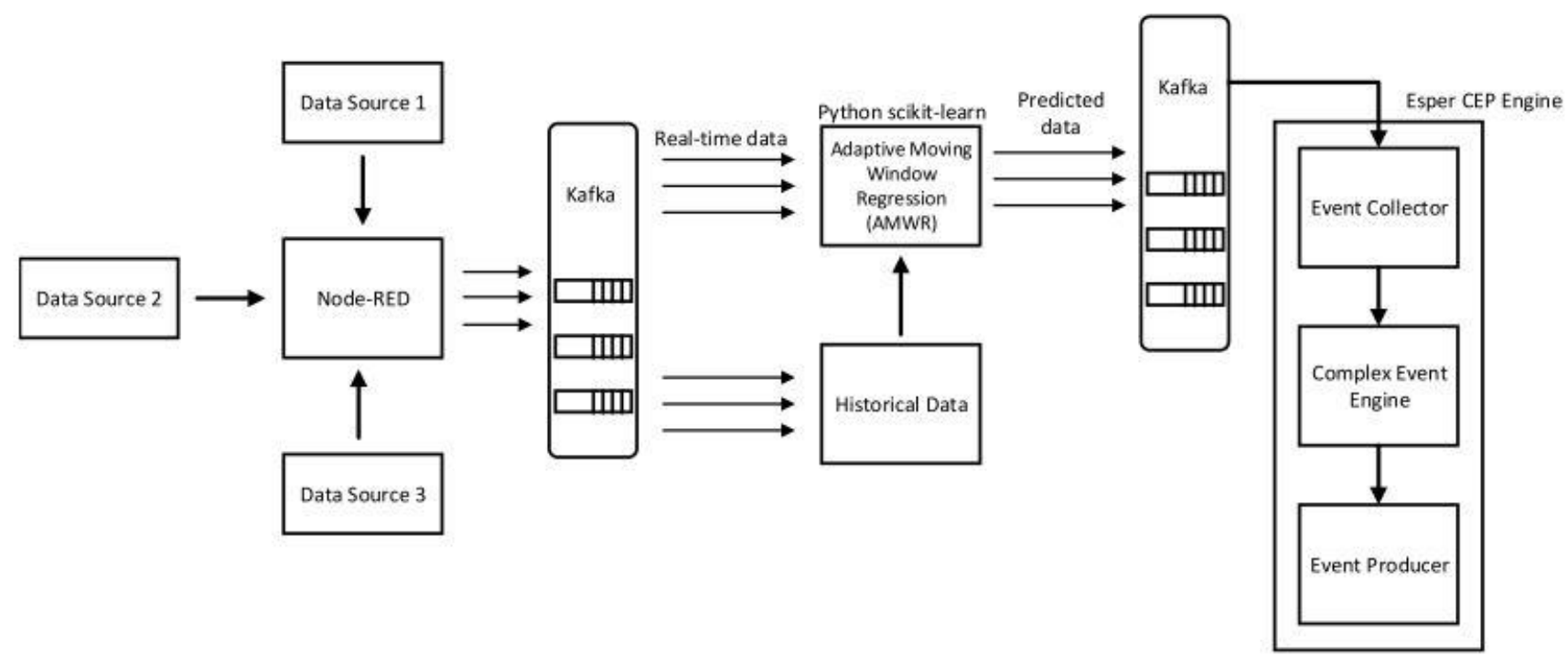

Gambar 2 Arsitektur Akbar dkk - Gambar diambil dari [6] 


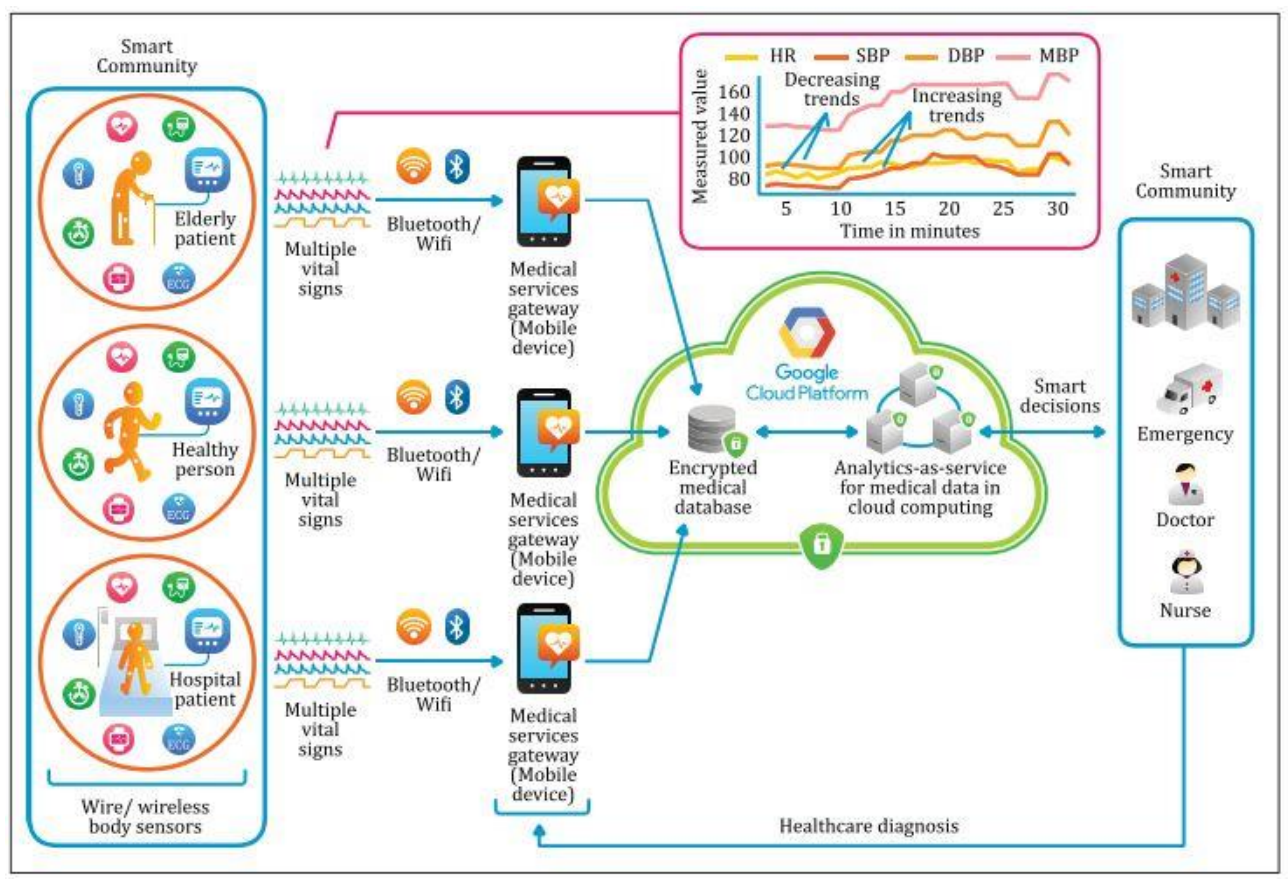

Gambar 3 Arsitektur Abdulatif dkk - Gambar diambil dari [3]

Berdasarkan gambar 2, Node-RED bertugas sebagai front end dimana data yang berasal dari sumbersumber yang berbeda diakses kemudian data tersebut dilakukan preprocessing seperti filtering data redundan dan mengubah format data yang dibutuhkan. Preprocessing data dilakukan oleh Kafka. Data real time dan data historis diakses dari kafka kemudian dilakukan prediksi menggunakan model AMWR yang mempresentasikan komponen ML. Model AMWR terdiri dari tiga langkah utama yaitu pemilihan algoritma regresi, menemukan optimum training window size, dan ukuran horizon prediksi. Data prediksi dimasukkan pada Kafka dalam bentuk event tuple. Kafka merupakan open source tool untuk publish dan subscribe data secara real time.

\subsubsection{Arsitektur Abdulatif dkk}

Arsitektur yang diusulkan Abdulatif dkk menyediakan kerangka kerja pendeteksian perubahan real-time dan prediksi abnormal berbasis cloud yang menjaga privasi untuk beberapa tanda vital pasien. Arsitektur ini digunakan pada sistem kesehatan cerdas untuk memprediksi atau deteksi dini penyakit pasien. Arsitektur Abdulatif dkk ditunjukkan pada gambar 3.

Arsitektur Abdulatif dkk memiliki tiga entitas utama, yaitu sebagai berikut:

- Smart Community Resident (SCR): Data-data tanda vital pada warga masyarakat dapat dikumpulkan dan dikirim secara langsung langsung ke penyimpanan berbasis cloud.

- $\quad$ Cloud Storage (CS): Digunakan untuk menyimpan data SCR dalam bentuk terenkripsi.

- Smart Prediction Model (SPM): Entitas inti dari sistem ini dimana data terenkripsi yang terkumpul diproses berdasarkan model matematika untuk mendeteksi perubahan abnormal pada tanda-tanda vital SCR.

Ketiga entitas tersebut berkolaborasi untuk memantau dan memperkirakan tanda-tanda vital setiap SCR. Setelah data terenkripsi dikirim ke CS, SPM bekerja secara independen untuk menganalisis data terenkripsi secara aman (tanpa mendekripsi). SCR dapat mengambil hasil terenkripsi melalui CS dan dapat didekripsi secara aman hanya di sisi SCR.

\subsubsection{Arsitektur Jo dkk}

Arsitektur Jo dkk didesain secara khusus untuk sistem monitoring dan penilaian kualitas udara di tambang batubara bawah tanah. Arsitektur ini mengusulkan kerangka utama yang terdiri dari akuisisi data, 
transmisi data, pemrosesan data (untuk penilaian dan prediksi kualitas udara) dan layanan untuk berbagi informasi dan kontrol cerdas pada ventilator tambang. Arsitektur ini ditunjukkan pada gambar 4.

Dalam sistem ini, unit penginderaan didasarkan pada modul sensor yang terpasang pada Arduino. Dua unit penginderaan membentuk Sensor Nodes (SN), yang menangkap data terkait kualitas udara dan mengirimkan data ini ke stasiun induk melalui ZigBee. Stasiun induk menjalankan Azure Machine Learning (AML), yang beroperasi sebagai platform as service (PaaS). Model kualitas udara mengekstraksi jenis polutan dan memprediksi kualitas udara berdasarkan konsentrasi polutan. Dengan demikian, sistem ini melakukan pengambilan keputusan dan kontrol otonom berbasis AML.

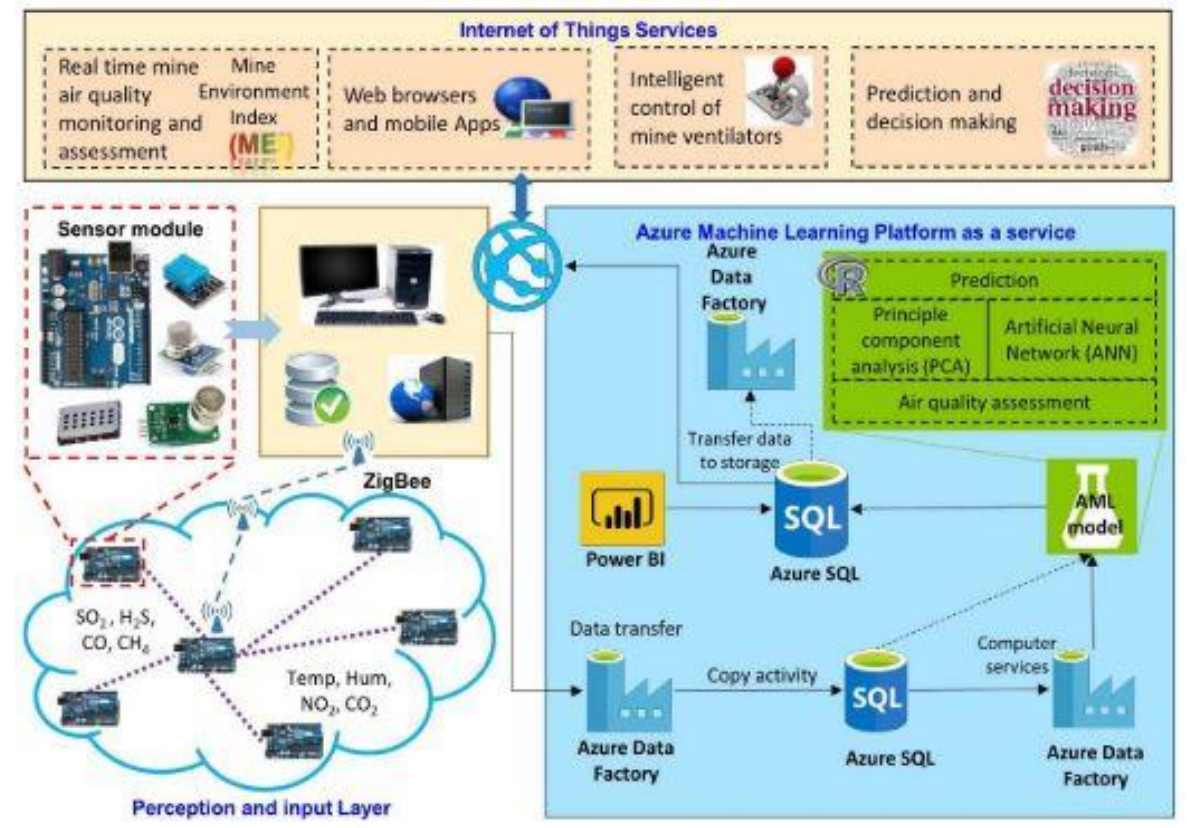

Gambar 4 Arsitektur Jo dkk - Gambar diambil dari [29]

\subsubsection{Arsitektur Patil dkk}

Penelitian yang diusulkan oleh patil dkk berfokus pada penggunaan perangkat IOT yang efektif dan algoritma yang efisien untuk perbaikan data penginderaan dan prediksi dengan pembelajaran keputusan. Arsitektur sistem ini digunakan pada sistem pertanian cerdas untuk memprediksi pertumbuhan dan penyakit tanaman. Pada desain sistem ini, Patil dkk memasukkan aliran komunikasi antara komponen sistem dan input/output yang berbeda untuk modul dalam sistem yang berbeda. Arsitektur Patil dkk ditunjukkan pada Gambar 5.

Komponen utama sistem terdiri dari tiga hal yaitu: Perangkat IOT, Algoritma perbaikan data dan Algoritma pembelajaran mesin untuk prediksi. Perangkat IoT bertugas untuk mengumpulkan data-data seperti kelembaban, temperatur, dan kondisi tanaman. Komponen IoT, seperti And Cube (IoT Gateway) dan Mobius (platform Layanan IoT), diintegrasikan dalam sistem usulan untuk memberikan solusi cerdas pada pemantauan pertumbuhan tanaman. Algoritma perbaikan data menggunakan Kalman Filter (KF) untuk memfilter data agar data yang diperoleh berkualitas tanpa noise sebelum data tersebut digunakan untuk prediksi. Algoritma analisis prediktif yang digunakan untuk pengambilan keputusan adalah Decision tree. Hasil prediksi pada sistem ini yaitu prediksi hasil panen, klasifikasi tanaman, klasifikasi tanah, prediksi cuaca, dan prediksi penyakit tanaman. 


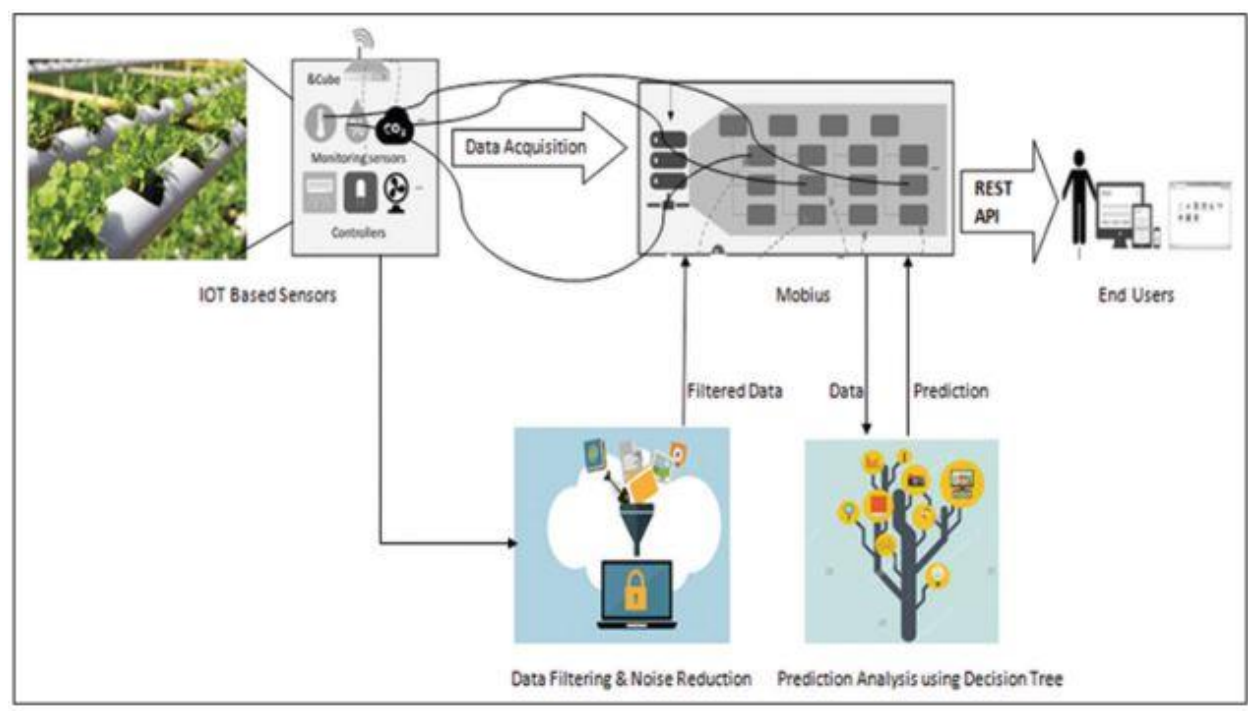

Gambar 5 Arsitektur Patil dkk - Gambar diambil dari [17]

\section{KESIMPULAN}

Penelitian ini berhasil mengidentifikasi dan menganalisis tren, metode dan arsitektur yang digunakan pada analisis prediktif dengan IoT berdasarkan research question yang diajukan dengan SLR antara tahun 2015 2019 pada beberapa database jurnal populer. Berdasarkan formula keyword ditemukan 674 paper kemudian dengan menerapkan kriteria inclusion dan exclusion maka terpilih 30 paper yang akan di-review. Adapun hasil review sebagai berikut; tren bidang penelitian analisis prediktif dengan IoT yaitu Transportasi, Pertanian, Kesehatan, Industri, Smart Home, dan Lingkungan. Saat ini, bidang pertanian merupakan bidang yang paling banyak diteliti misalnya prediksi penyakit tanaman, pemantauan pertumbuhan tanaman, dan prediksi stres pada sapi perah. Metode yang digunakan pada analisis prediktif dengan IoT bermacam-macam sesuai kondisi data yang dipakai. Terdapat lima metode yang paling banyak digunakan yaitu Bayesian Network (BN), Artificial Neural Network (ANN), Recurrent Neural Networks (RNN), Neural Network (NN), dan Support Vector Machines (SVM). Masing-masing metode memiliki tingkat akurasi prediksi yang berbeda-beda. Beberapa peneliti mengusulkan metode perbaikan dari beberapa metode. Metode perbaikan menunjukkan tingkat akurasi prediksi yang lebih baik. Hasil dari penelitian ini juga mengidentifikasi empat macam arsitektur yang diusulkan yaitu Arsitektur Akbar dkk, Arsitektur Abdulatif dkk, Arsitektur Jo dkk, dan Arsitektur Patil dkk.

\section{REFERENSI}

[1] L. Andrade, R. Rios, T. Nogueira, dan C. Prazeres, "Applying classification methods to model standby power consumption in the Internet of Things," Proc. 2017 IEEE 14th Int. Conf. Networking, Sens. Control. ICNSC 2017, hal. 537-542, 2017.

[2] F. Carrez et al., "Real-Time Probabilistic Data Fusion for Large-Scale IoT Applications," IEEE Access, vol. 6, hal. 10015-10027, 2018.

[3] A. Alabdulatif, I. Khalil, A. R. M. Forkan, dan M. Atiquzzaman, "Real-Time Secure Health Surveillance for Smarter Health Communities," IEEE Commun. Mag., vol. 57, no. 1, hal. 122-129, 2019.

[4] S. Kim, M. Lee, dan C. Shin, "IoT-based strawberry disease prediction system for smart farming," Sensors (Switzerland), vol. 18, no. 11, hal. 1-17, 2018.

[5] Y. Elsaadany, A. J. A. Majumder, dan D. R. Ucci, “A Wireless Early Prediction System of Cardiac Arrest through IoT,” Proc. - Int. Comput. Softw. Appl. Conf., vol. 2, hal. 690-695, 2017.

[6] A. Akbar, A. Khan, F. Carrez, dan K. Moessner, "Predictive analytics for complex IoT data streams," IEEE Internet Things J., vol. 4, no. 5, hal. 1571-1582, 2017.

[7] K. Bhargava dan S. Ivanov, "Collaborative Edge Mining for predicting heat stress in dairy cattle," IFIP 
Wirel. Days, vol. 2016-April, hal. 1-6, 2016.

[8] D. Kwon dan M. R. Hodkiewicz, "IoT-Based Prognostics and Systems Health Management for Industrial Applications,” IEEE Access, hal. 3659-3670, 2016.

[9] A. Dresch, D. Pacheco, L. Jos, V. A. Jr, dan T. Advancement, Design Science Research: A method for Science and Technology Advancement. Springer International Publishing Switzerland, 2015.

[10] X. Ma, H. Yu, Y. Wang, dan Y. Wang, "Large-Scale Transportation Network Congestion Evolution Prediction Using Deep Learning Theory," PLoS One, hal. 1-17, 2015.

[11] D. Goel, S. Chaudhury, dan H. Ghosh, "An IoT approach for context-aware smart traffic management using ontology," Proc. Int. Conf. Web Intell., hal. 42-49, 2017.

[12] Y. Wang dan Q. Li, "Proactive Complex Event Processing for transportation Internet of Things," 2015 IEEE 34th Int. Perform. Comput. Commun. Conf. IPCCC 2015, hal. 1-2, 2016.

[13] Y. Zheng, S. Rajasegarar, dan C. Leckie, "Parking availability prediction for sensor-enabled car parks in smart cities," 2015 IEEE 10th Int. Conf. Intell. Sensors, Sens. Networks Inf. Process. ISSNIP 2015, no. April, hal. 1-6, 2015.

[14] F. Bromberg, D. Dujovne, T. Watteyne, A. L. Diedrichs, dan K. Brun-Laguna, "Prediction of Frost Events Using Machine Learning and IoT Sensing Devices," IEEE Internet Things J., vol. 5, no. 6, hal. 4589-4597, 2018.

[15] D. Karimanzira dan T. Rauschenbach, "Enhancing aquaponics management with IoT-based Predictive Analytics for efficient information utilization," Inf. Process. Agric., no. xxxx, 2019.

[16] X. Liu et al., "Application of Temperature Prediction Based on Neural Network in Intrusion Detection of IoT,” Secur. Commun. Networks, vol. 2018, 2018.

[17] S. M. Patil dan S. R, "Internet of Things Based Smart Agriculture System Using Predictive Analytics," Asian J. Pharm. Clin. Res., vol. 10, no. 13, hal. 148, 2017.

[18] T. Truong, A. Dinh, dan K. Wahid, "An IoT environmental data collection system for fungal detection in crop fields," Can. Conf. Electr. Comput. Eng., hal. 1-4, 2017.

[19] P. Sundaravadivel, K. Kesavan, L. Kesavan, S. P. Mohanty, dan E. Kougianos, "Smart-Log: A DeepLearning Based Automated Nutrition Monitoring System in the IoT," IEEE Trans. Consum. Electron., vol. 64, no. 3, hal. 390-398, 2018.

[20] T. R. Mauldin, M. E. Canby, V. Metsis, A. H. H. Ngu, dan C. C. Rivera, "Smartfall: A smartwatchbased fall detection system using deep learning," Sensors (Switzerland), vol. 18, no. 10, hal. 1-19, 2018.

[21] M. F. Ijaz, "Hybrid Prediction Model for Type 2 Diabetes and Hypertension Using DBSCAN-Based Outlier Detection, Synthetic Minority Over Sampling Technique ( SMOTE ), and Random Forest," Appl. Sci., 2018.

[22] D. Iakovakis dan L. Hadjileontiadis, "Standing hypotension prediction based on smartwatch heart rate variability data,” Int. Conf. Human-Computer Interact. with Mob. Devices Serv., hal. 1109-1112, 2016.

[23] J. Siryani, B. Tanju, dan T. J. Eveleigh, "A Machine Learning Decision-Support System Improves the Internet of Things' Smart Meter Operations," IEEE Internet Things J., vol. 4, no. 4, hal. 1056-1066, 2017.

[24] Y. Kwon, J. Lee, J. Lee, dan M. Choi, "A study on the P.H.A.S (Piezoelectric energy Harvesting based Access control System) using motor vibration," Int. Conf. Control. Autom. Syst., vol. 2017-Octob, no. Iccas, hal. 1426-1428, 2017.

[25] B. D. Minor, J. R. Doppa, dan D. J. Cook, "Learning activity predictors from sensor data: Algorithms, evaluation, and applications," IEEE Trans. Knowl. Data Eng., vol. 29, no. 12, hal. 2744-2757, 2017.

[26] I. Ullah, R. Ahmad, dan D. H. Kim, "A prediction mechanism of energy consumption in residential buildings using hidden markov model," Energies, vol. 11, no. 2, hal. 1-20, 2018.

[27] N. S. Khan, S. Ghani, dan S. Haider, "Real-time analysis of a sensor's data for automated decision making in an IoT-based smart home," Sensors (Switzerland), vol. 18, no. 6, hal. 1-20, 2018.

[28] V. Edmondson, M. Cerny, M. Lim, B. Gledson, S. Lockley, dan J. Woodward, “A smart sewer asset (C)Asosiasi Prakarsa Indonesia Cerdas (APIC) - 2020 
information model to enable an 'Internet of Things' for operational wastewater management," Autom. Constr., vol. 91, no. March, hal. 193-205, 2018.

[29] B. W. Jo dan R. M. A. Khan, "An internet of things system for underground mine air quality pollutant prediction based on azure machine learning," Sensors (Switzerland), vol. 18, no. 4, 2018.

[30] T. Bakhshi dan M. Ahmed, "IoT-Enabled Smart City Waste Management Using Machine Learning Analytics," Int. Conf. Energy Conserv. Effic., vol. 7, hal. 3-8, 2018.

[31] Y. Fu dan W. Wu, "Predicting household water use behaviour for improved hygiene practices in internet of things environment via dynamic behaviour intervention model," IET Networks, vol. 5, no. 5, hal. 143-151, 2016. 